\title{
Overexpression of Apolipoprotein CII Causes Hypertriglyceridemia in Transgenic Mice
}

\author{
Neil S. Shachter, * Tony Hayek, " Todd Leff, ${ }^{\star}$ Jonathan D. Smith, " Daniel W. Rosenberg, ${ }^{3}$ Annemarie Walsh, * \\ Rajasekhar Ramakrishnan," Ira J. Goldberg," Henry N. Ginsberg," and Jan L. Breslow * \\ ${ }^{*}$ Laboratory of Biochemical Genetics and Metabolism, The Rockefeller University, New York 10021-6399; ${ }^{\ddagger}$ Parke-Davis \\ Pharmaceuticals, Department of Biotechnology, Ann Arbor, Michigan 48106; ${ }^{\S}$ The University of Connecticut, Section of Pharmacology \\ and Toxicology, Storrs, Connecticut 06268; and "Division of Preventive Medicine and Nutrition, Department of Medicine, Columbia \\ College of Physicians and Surgeons, New York 10032
}

\begin{abstract}
We have generated transgenic mice expressing the human apolipoprotein CII (apoCII) gene under the transcriptional control of the human cytochrome P-450 IA1 (CYPIA1) promoter. Human apoCII transgenic (HuCIITg) mice exhibited significant basal expression of the transgene (plasma apoCII level $=26.1 \pm 4 \mathrm{mg} / \mathrm{dl}$ ) and showed further induction of transgene expression after treatment with $\beta$-naphthoflavone. Unexpectedly, HuCIITg mice were hypertriglyceridemic and human apoCII levels correlated strongly to triglyceride levels ( $R$ $=0.89, P<0.0001)$. Triglyceride levels $(\mathrm{mg} / \mathrm{dl} \pm \mathrm{SEM})$ were elevated compared to controls in both the fed $(804 \pm 113$ vs $146 \pm 18, P<0.001)$ and fasted $(273 \pm 39$ vs $61 \pm 4, P<0.001)$ states. HuCIITg mice accumulated triglyceride-rich very low density lipoproteins (VLDL) with an increased apoC/apoE ratio. Tracer kinetic studies indicated delayed clearance of VLDL-triglyceride, and studies using Triton inhibition of VLDL clearance showed no increase in VLDL production. Plasma from these mice activated mouse lipoprotein lipase normally and radiolabeled VLDL were normally hydrolyzed. However, HuCIITg VLDL showed markedly decreased binding to heparin-Sepharose, suggesting that apoCII-rich, apoE-poor lipoprotein may be less accessible to cell surface lipases or receptors within their glycosaminoglycan matrices. HuCIITg mice are a promising model of hypertriglyceridemia that suggests a more complex role for apoCII in the metabolism of plasma triglycerides. (J. Clin. Invest. 1994. 93:1683-1690.) Key words: apolipoproteins C • cytochrome P-450 • lipoprotein lipase • very low density lipoproteins • transgenic mice
\end{abstract}

\section{Introduction}

$\mathrm{C}$ apolipoproteins have both unique and overlapping functions in the metabolism of triglyceride-rich lipoproteins. ApoCII has a central role in the trafficking of plasma triglyceride. It is the specific physiological activator of lipoprotein lipase (LPL) ${ }^{1}(1$, 2 ). Homozygous hereditary deficiency of apoCII leads to a

Address correspondence to Neil S. Shachter, Division of Preventive Medicine and Nutrition, Department of Medicine, Columbia College of Physicians and Surgeons, 630 West 168th Street, New York, NY 10032. The current address for Tony Hayek is Department of Internal Medicine D, Rambam Medical Center, Haifa 31096, Israel.

Received for publication 7 January 1993 and in revised form 3 December 1993.

J. Clin. Invest.

(C) The American Society for Clinical Investigation, Inc. 0021-9738/94/04/1683/08 $\$ 2.00$

Volume 93, April 1994, 1683-1690 hyperchylomicronemic syndrome very similar to hereditary LPL deficiency (3-5). The heterozygous state for one mutant apoCII allele, when associated with apolipoprotein E4, also is associated with hypertriglyceridemia (6). ApoCII, along with apoCI and apoCIII, interferes with the apoE-mediated removal of both chylomicrons and very low density lipoproteins (VLDL) by the perfused rat liver $(7,8)$. ApoCI and apoCII inhibit apoE-mediated binding of rabbit $\beta$-migrating VLDL to the low density lipoprotein receptor-related protein, a potential remnant receptor (9). Transgenic mice expressing human apoCI are mildly hypertriglyceridemic, supporting the postulated role for apoCI in remnant clearance (10). Transgenic mice overexpressing apoCIII are severely hypertriglyceridemic and show delayed VLDL clearance (11-12).

To further explore the role of the $\mathrm{C}$ apolipoproteins in lipoprotein metabolism, we attempted to create a human apoCII transgenic mouse. An initial construction using the native apoCII gene and its liver-specific enhancer ( 13) produced no transgenic mice. Because of concern that overexpression of apoCII may have caused the intrauterine death of transgenic fetuses, we redesigned the construction using the cytochrome P-450 IA 1 (CYPIA 1) promoter, which is normally silent in intrauterine life. CYPIA 1 is a xenobiotic-inducible gene expressed to a limited degree in many tissues but primarily in liver and proximal small intestine. The basal level of expression of the gene is very low. A variety of polycyclic aryl hydrocarbons have been shown to induce the gene including 3-methylcholanthrene and benz [a] anthracene (14). $\beta$-naphthoflavone $(\beta \mathrm{NF})$ is a relatively nontoxic agent that has been widely used for induction of CYPIAl gene expression and was therefore chosen for induction of expression of the transgene (15). We now report the successful generation of transgenic mice with regulatable hepatic and intestinal expression of the transgene. We also report the unexpected observation of marked hypertriglyceridemia, with accumulation of triglyceride-enriched VLDL in the plasma of human apoCII transgenic mice.

\section{Methods}

Plasmid construction. Standard recombinant DNA techniques were used. Clone 1604.CAT was a gift from Daniel W. Nebert, National Institute of Child Health and Human Development (Bethesda, MD) and contained the human CYPIA 1 promoter (16) with a 5 ' terminus at a false HindIII site-1604 to the start of transcription and a 3 ' terminus at a false HindIII site generated at +294 relative to the start of transcrip-

1. Abbreviations used in this paper: $\beta \mathrm{NF}, \beta$-naphthoflavone; chylo, chylomicron; CYPIA1, cytochrome P-450 IA 1; HuCIITg, human apoCII transgenic; IDL, intermediate density lipoproteins; LPL, lipoprotein lipase; VLDL, very low density lipoproteins. 
tion, 202 bp into CYPIA1 intron I. The insert of 1604.CAT was cloned into the HindIII site of pG9k, a modification of pGEM9zf(-) (Promega Corp., Madison, WI) with the NotI site converted to a KpnI site., creating pG9k450. Cosmid 20 containing the human apoCII gene and downstream sequences was the generous gift of Marten Hofker, University of Leiden (Leiden, The Netherlands) (17). A 6-kb fragment was isolated extending from a unique BspEI site present -4 bp to the transcription initiation site of apoCII to a HindIII site $3.5 \mathrm{~kb} \mathrm{3}$ to the gene and was blunt-end ligated into the Nsil site of pG9k450. The resulting clone, p450CII, was sequenced by the dideoxynucleotide method across all junctions to establish the correct orientation of the CYPIA1 promoter and apoCII gene inserts. The entire apoCII coding sequence of $\mathrm{p} 450 \mathrm{CII}$ was sequenced to exclude the possibility of mutation during cloning. Plasmids were prepared by alkaline lysis and banded twice through cesium chloride-ethidium bromide gradients.

Transgenic mice. The insert of $\mathrm{p} 450 \mathrm{CII}$ was obtained by KpnI/SalI digestion and $0.7 \%$ agarose gel electrophoresis. DNA was extracted from the gel using Qiaex resin (Qiagen, Inc., Chatsworth, CA) and further purified on an Elutip column (Schleicher \& Schuell, Inc., Keene, $\mathrm{NH}$ ). Transgenic mice were created as previously described (18). The fertilized eggs microinjected with the DNA construction were $(\mathrm{C} 57 \mathrm{Bl} / 6 \mathrm{~J} \times \mathrm{CBA} / \mathrm{J}) \mathrm{F}_{1}$. Integration of the human apoCII gene was determined by Southern blotting of tail-derived DNA. Gel-purified insert of a previously described apoCII cDNA, pCII-711, was labeled by the random-primed oligonucleotide technique and used as a probe $(19,20)$.

Animals. Offspring of a single male transgenic founder crossed to two $(\mathrm{C} 57 \mathrm{Bl} / 6 \mathrm{~J} \times \mathrm{DBA} / 2 \mathrm{~J}) \mathrm{F}_{1}$ females were used, except as indicated. Nontransgenic litter mates were used as controls in all studies. Transgenic offspring were initially identified by Southern blotting and subsequently by rocket immunoelectrophoresis, as described (12). The animals were caged in an animal care facility with a 7 a.m.-7 p.m. period of light. Except where otherwise indicated, both male and female mice were used at 2-4 mo of age, when they weighed 20-28 g.

Animals were fed a diet previously shown not to induce CYPIA1 (diet 90132; Teklad Premier Laboratory Diets, Madison, WI) (21). The composition of the diet by weight was $23 \%$ protein (casein), $4.8 \%$ total fat $(4.5 \%$ corn oil, $0.26 \%$ residual fat from casein, and $0.05 \%$ residual fat from corn starch), $5.8 \%$ crude fiber, and the remainder carbohydrate as equal weights of sucrose and corn starch. No cholesterol was added to the diet. Access to food was ad lib when not otherwise indicated. The blood samples used for the correlation of human apoCII levels with triglycerides (see Fig. 3 ) were drawn at 9 a.m., with food removed the previous 6 p.m. Fasting bloods cited in all other tables and figures were drawn at 5 p.m., $9 \mathrm{~h}$ after the removal of food. Postprandial ("fed") bloods were drawn at 9 a.m. Animals were anesthetized with methoxyflurane for retroorbital phlebotomy and intravenous femoral injections.

Promoter induction. CYPIAl promoter induction was performed by intraperitoneal injection of a sonicated suspension of $14 \mathrm{mg} / \mathrm{ml}$ $\beta$-naphthoflavone in corn oil. $60 \mu \mathrm{l}$ of this suspension was used for induction before the RNase protection assay. $200 \mu \mathrm{l}$ of the suspension, containing $\sim 180 \mathrm{mg}$ of triglyceride and equivalent to $\sim 130 \mathrm{mg} / \mathrm{kg}$ of $\beta$-naphthoflavone (about three times the dose effective in rats) was empirically found to induce protein expression and was used for induction in other experiments (22). Control injections were performed with the corn oil vehicle. Injections were performed $9 \mathrm{~h}$ before "fasting" bloods and $12 \mathrm{~h}$ before "fed" bloods, and they were well-tolerated by the animals.

RNase protection assay. The apoCII RNA probe was derived by cloning the 500-bp PstI insert from pCII-711 into pGEM1 (Promega Corp.) Orientation was determined by restriction digestion. RNase protection assay was performed as described on $10 \mu \mathrm{g}$ of total RNA extracted from the tissues of male high expressing animals (23). The gels were scanned using laser densitometer (Ultroscan XL; LKB Instruments, Inc., Gaithersburg, MD).

Lipoprotein analysis. Triglyceride and cholesterol concentrations were performed using commercial kits (no. 126012 and no. 236691, respectively; Boehringer Mannheim Corp., Indianapolis, IN). Phospholipids were determined as total phosphorus (24). Statistical comparisons of lipoprotein data between different states were by paired $t$ test, using the same animals. Comparisons between controls and transgenics were by unpaired $t$ test. Statistical analyses compared the logarithm of triglyceride levels and the cholesterol and apoCII levels as measured. VLDL $(d<1.006 \mathrm{~g} / \mathrm{ml})$, intermediate density lipoproteins (IDL) + LDL $(d=1.006-1.063 \mathrm{~g} / \mathrm{ml})$ and HDL $(d=1.063-1.21 \mathrm{~g} / \mathrm{ml})$, were separated by sequential density ultracentrifugation of pooled mouse plasma (25). Each fraction was reisolated from a second ultracentrifugation at the same density before analysis. Protein concentrations in lipoprotein fractions were determined by the method of Lowry et al. with bovine serum albumin as the standard (26). Gel filtration chromatography was performed on $200 \mu$ l of pooled mouse plasma using two Superose 6 columns in series (FPLC; Pharmacia Fine Chemicals, Piscataway, NJ). $400.5-\mathrm{ml}$ fractions were collected and assayed for cholesterol and triglyceride.

Apolipoprotein CII quantitation. Human apoCII levels in mouse plasma were determined by rocket immunoelectrophoresis using a goat polyclonal antiserum to human apoCII (without cross-reactivity to normal mouse plasma) and a purified human apoCII standard (Daiichi Pure Chemicals, Tokyo, Japan), as described for apoCIII (12).

Apolipoprotein composition. VLDL total protein was quantitated by the method of Lowry (26). To identify apolipoproteins, $5 \mu \mathrm{g}$ of VLDL protein was isolated by a single ultracentrifugation to minimize losses of small apolipoproteins and analyzed by $3-15 \%$ gradient SDSPAGE (27). After staining in $45 \%$ methanol, $10 \%$ acetic acid, $0.1 \%$ Coomassie blue $\mathrm{R}$ and destaining in $30 \%$ methanol, $10 \%$ acetic acid, the gels were scanned using a laser densitometer (Ultroscan XL; LKB Instruments, Inc.), and the apoE/apoC ratio was calculated.

Preparation of labeled VLDL. Triglyceride-labeled VLDL was produced by minor modification of a described protocol $(12) .\left[{ }^{3} \mathrm{H}\right]-$ palmitic acid dissolved in ethanol ( TRK.909; Amersham Corp. Arlington Heights, IL) or $\left[{ }^{3} \mathrm{H}\right]$ oleate dissolved in toluene (NET 289; New England Nuclear, Boston, MA) was evaporated under nitrogen and redissolved overnight at room temperature in $150 \mathrm{mM} \mathrm{NaCl}$ containing $324 \mu \mathrm{g} / \mathrm{ml}$ fatty acid-free bovine serum albumin (A-7511 Sigma Immunochemicals, St. Louis, MO) at a final concentration of $250 \mu \mathrm{Ci}$ / $\mathrm{ml}$. Mice were injected with $50-75 \mu \mathrm{Ci}$ i.v. and bled at $45 \mathrm{~min}$ after the injection. The radiolabeled VLDL used for clearance studies was isolated by single-spin ultracentrifugation $(\mathrm{d}<1.006 \mathrm{~g} / \mathrm{ml})$. To minimize the amount of VLDL-associated albumin, the VLDL used for binding studies and lipolysis was reisolated after a second ultracentrifugal spin. Thin layer chromatography on plastic silica gel 60 plates (E. Merck, Darmstadt, Germany) using hexane-diethyl ether-acetic acid (90:10:1) was performed on the VLDL to insure that unincorporated fatty acid was $<20 \%$ of triglyceride.

$V L D L$ clearance studies. Turnover studies were done in male offspring of the founder mouse and $(\mathrm{C} 57 \mathrm{Bl} / 6 \mathrm{~J} \times \mathrm{CBA} / \mathrm{J}) \mathrm{F}_{1}$ or $(\mathrm{C} 57 \mathrm{Bl} /$ $6 \mathrm{~J} \times \mathrm{DBA} / 2 \mathrm{~J}) \mathrm{F}_{1}$ females and in controls of comparable genetic background essentially as described (12). Studies were done between 10 a.m. and 2 p.m. Eight control and six human apoCII transgenic (HuCIITg) mice were injected with $100,000 \mathrm{dpm}$ i.v. of ${ }^{3} \mathrm{H}$-labeled VLDL obtained from control mice. The disappearance of labeled VLDL was determined by counting $40-\mu$ l samples of plasma obtained from $90-\mu \mathrm{l}$ aliquots of blood drawn at 2, 5, 10, 20,40, 75, and 120 min after injection. Total plasma radioactivity at each time point primarily represents VLDL radioactivity, as has been experimentally validated (12). The data were modeled either by a single pool model of triglyceride kinetics or by a two-pool model (main pool and remnant pool derived from the main pool) if it improved the fit of the data, as has been described $(12,28)$. Computerized statistical analysis was done with SAS (SAS Institute, Cary, NC). Comparison of triglyceride levels, fractional catabolic rates, and production rates was by $t$ test.

Triglyceride production rates. 10 control and $5 \mathrm{HuCIITg}$ mice were anesthetized and injected with $500 \mathrm{mg} / \mathrm{kg}$ i.v. Triton WR 1339 as a 15 $\mathrm{g} / \mathrm{dl}$ solution in $0.9 \% \mathrm{NaCl}$, as described (12). Plasma VLDL clearance in mice is virtually completely inhibited in both control and hypertri- 
glyceridemic mice under these conditions (12). Studies were done between 10 and $2 \mathrm{pm}$, at which time chylomicrons are absent. $60-\mu \mathrm{l} \mathrm{blood}$ samples were drawn at 10,30, and 60-min after the injection. Triglycerides were measured on the separated plasma and production rates were calculated by linear regression and compared by $t$ test.

Lipase assay. Control $\mathrm{C} 57 \mathrm{Bl} / 6 \mathrm{~J} \times \mathrm{CBA} / \mathrm{J} \mathrm{F}_{1}$ mice weighing 25-30 $\mathrm{g}$ were injected with $10 \mathrm{U}$ of bovine heparin and exsanguinated after 1 min. Samples were kept on ice until the plasma was separated and frozen at $-70^{\circ} \mathrm{C}$. Lipoprotein lipase ( $\mathrm{LPL}$ ) was purified by affinity chromatography by a modification of the method of Augustin et al. (29). $3 \mathrm{ml}$ of postheparin plasma was mixed with an equal volume of packed heparin-Sepharose (Pharmacia CL-6B swollen with PBS, pH 7.4 ), rocked at $4^{\circ}$ for $2 \mathrm{~h}$, and packed into a column. The column was washed with $15 \mathrm{ml}$ of PBS. $151.3-\mathrm{ml}$ fractions were collected with a buffer containing $0.75 \mathrm{M}$ sodium chloride, $10 \mathrm{mM}$ sodium phosphate, $\mathrm{pH}$ 7.4. 16 fractions were collected with $1.5 \mathrm{M}$ sodium chloride buffer. Fractions were frozen at $-70^{\circ}$. A $100-\mu$ l aliquot of the initial runthrough and of each column fraction was assayed for lipase activity. Activity eluting with $0.75 \mathrm{M} \mathrm{NaCl}$ was assumed to represent hepatic lipase. LPL activity eluted with $1.5 \mathrm{M} \mathrm{NaCl}$ and required plasma for activation. Lipase assays were performed as described by Brinton et al. with the omission of anti-LPL antibodies (30). The third and fourth fractions of the $1.5 \mathrm{M} \mathrm{NaCl}$ eluate were pooled and a $25-\mu \mathrm{l}$ aliquot was added to a triglyceride emulsion activated with varying amounts of fasting plasma from either control or a HuCIITg mouse. The HuCIITg mouse had a noninduced fasting plasma human apoCII level of 30 $\mathrm{mg} / \mathrm{dl}$, typical for day-period fasted mice. Assays were performed in quadruplicate.

$V L D L$ binding assay. ${ }^{3} \mathrm{H}$-labeled VLDL isolated from HuCIITg and control mice were incubated with heparin-Sepharose (Pharmacia Fine Chemicals) according to a modification of the protocol of Agnani, G., C. Dachet, B. Leroy, L. Guermani, F. T. Yen, C. J. Mann, N. Hubert, I. J. Goldberg, B. Jacotot, and B. E. Bihain (personal communication). VLDL at $50 \mu \mathrm{g}$ protein $/ \mathrm{ml}$ in $100 \mathrm{mM}$ Tris, $100 \mathrm{mM} \mathrm{NaCl}, 2$ $\mathrm{mM} \mathrm{CaCl}$, and $0.2 \mathrm{~g} / \mathrm{dl} \mathrm{BSA}, \mathrm{pH} 7.4$, were incubated for $2 \mathrm{~h}$ at $37^{\circ} \mathrm{C}$ with an equal volume $(0.5 \mathrm{ml})$ of heparin-Sepharose gel, preswollen in the same buffer. The buffer was removed and the gel was washed three times with fresh buffer. An equal volume of buffer containing 100 $\mathrm{U} / \mathrm{ml}$ of heparin was added and incubated at $37^{\circ} \mathrm{C}$ for $10 \mathrm{~min}$. The buffer was removed and the ${ }^{3} \mathrm{H}$ remaining in the gel, heparin eluate, and initial buffer was determined. The experiment was performed in triplicate for each preparation.

\section{Results}

Human apoCII gene sequences beginning at -4 bp relative to the start of transcription and extending $3.5 \mathrm{~kb} 3^{\prime}$ to the gene were joined to the human CYPIA1 promoter (Fig. 1). The resulting DNA construction was microinjected into fertilized mouse eggs. Pups were screened by Southern blot and a transgenic founder was identified. All further studies were done on the progeny of this mouse.

Expression of the apoCII transgene at the RNA level was documented by RNase protection assay (Fig. 2). In the noninduced state, expression of the human apoCII gene was demonstrated in brain and liver along with a very low level of proximal-intestinal expression. After induction with $\beta \mathrm{NF}$, brain expression decreased by $43 \%$ and liver expression increased $\sim 2.5$-fold, while proximal small intestinal expression increased dramatically (>100-fold). There was no detectable expression in fat, heart, distal small intestine, colon, kidney, skin, or spleen. Assay of human hepatoma (HepG2) RNA revealed the same size protected fragment and no signal was present in tissues from nontransgenic mice (data not shown).

We then analyzed the plasma of the transgenic mice for human apoCII protein and fasting lipid levels. All direct comparisons between states describe the same mice under the various conditions. As predicted by the RNase protection assay, there was significant human apoCII in the plasma of the transgenic mice in the absence of administered inducer. $\mathrm{Hu}$ man apoCII levels in transgenics, determined by quantitative rocket immunoelectrophoresis after an overnight fast, were surprisingly variable and ranged from 2.2 to $14 \mathrm{mg} / \mathrm{dl}$ (mean \pm SEM, 8.1 \pm 0.9 ). In comparison, the fasting apoCII level in normal humans is $3.6 \pm 1.0 \mathrm{mg} / \mathrm{dl}$ (31). ApoCII levels were highly correlated with plasma triglyceride $(\mathrm{R}=0.89$ and $P<0.000$, Fig. 3). Mean triglyceride levels were $283 \pm 40$ in transgenics vs $130 \pm 14$ in controls $(P<0.05)$.

With day-period fasting, which was used in the subsequent experiments, noninduced HuCIITg mice showed a degree of hypertriglyceridemia similar to the overnight-fasted values. Triglyceride values increased markedly with feeding. Transgenic mice had an approximately fivefold increase in plasma triglyceride compared to controls in both the fasted and fed states. Fasting triglyceride levels were $273 \pm 39$ (range $=99-635$ ) vs $61 \pm 4$ in controls $(P<0.001)$. In the fed state, the mean triglyceride level in transgenics increased to $804 \pm 113$ (range $=264$ 1746) vs $146 \pm 18$ in controls $(P<0.001$ fed transgenics vs controls and $P<0.0001$ fed vs fasted transgenics).

$\beta \mathrm{NF}$ induction increased the apoCII protein and triglyceride levels in the fasted state (Table I). Human apoCII levels after day-period fasting were $26.1 \pm 4 \mathrm{mg} / \mathrm{dl}$ (higher than after the nocturnal fast ) and increased to $38.3 \pm 1$ after $\beta$ NF induction $(P<0.03)$. As the inducer was administered in corn oil, some increase in triglycerides was observed with the vehicle alone. Statistical comparisons of triglyceride levels were made between inducer and vehicle injections. After promoter induction in transgenic mice there was a $66 \%$ increase in fasting triglycerides vs the levels in the same mice after the injection of vehicle alone. This was statistically significant at $P<0.001$. A small increase in fasting triglyceride levels after injection of the $\beta N F$ suspension into control mice was not statistically significant. Cholesterol levels in transgenics were moderately higher than controls, whether noninduced $(P<0.05)$ or induced $(P$ $<0.001)$. Cholesterol levels in transgenic mice after induction were significantly higher than in the noninduced state $(P$ $<0.001$ ).

Gel filtration chromatography was performed on pooled plasma from 10 control and $10 \mathrm{HuCIITg}$ mice and revealed a marked increase in chylomicron (chylo) + VLDL triglyceride and a slight increase in triglyceride within IDL + LDL and HDL. Cholesterol was elevated in chylo + VLDL ( to a lesser

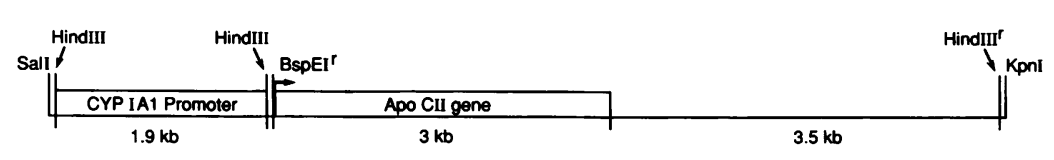

p450CII
Figure 1. The insert of p450CII. The human apoCII gene is under the transcriptional control of the human CYPIA 1 promoter. Vertical lines above the baseline indicate restriction sites. Lines below the baseline demarcate distances in $\mathrm{kb}$. The horizontal arrow indicates the physiological start site of apoCII gene transcription. 
Fed, Induced Fed, Noninduced

$P \quad t \quad B F H I_{1} I_{2} I_{3} K L S k S p B F H I_{1} I_{2} I_{3} \mathrm{KL} \mathrm{SkSp}$

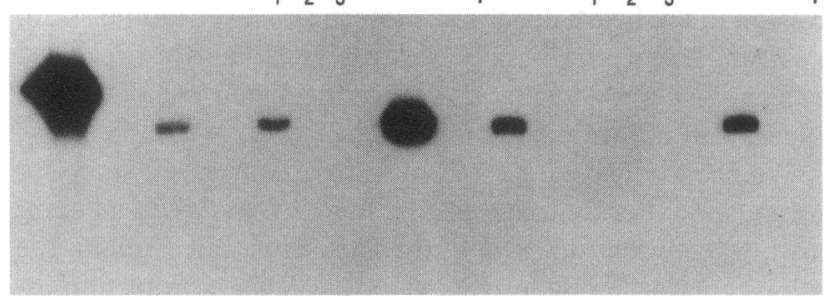

Figure 2. An RNase protection gel assay detecting human apoCII transcripts. $P$, probe alone; $t$, probe hybridized to yeast transfer RNA; $B$, brain; $F$, adipose tissue; $H$, heart; $I_{1}$, proximal small intestine (s.i.); $I_{2}$, mid s.i.; $I_{3}$, distal s.i. and colon; $K$, kidney; $L$, liver; $S k$, skin; $S p$, spleen. Induced, $12 \mathrm{~h}$ after the intraperitoneal injection of $840 \mu \mathrm{g} \beta$ naphthoflavone. Expression is evident only in liver, brain, and minimally, in proximal small intestine in the absence of inducer. There is a dramatic increase in small intestinal and hepatic (but not brain) expression after induction.

extent than triglyceride), slightly elevated in IDL + LDL and unchanged in HDL (Fig. 4). Sequential density ultracentrifugation was also performed using pooled plasma from $5 \mathrm{HuCIITg}$ mice and 15 controls with compositional analysis of lipoprotein fractions (Table II). There was a marked increase in VLDL triglyceride levels in HuCIITg mice. VLDL cholesterol increased to a lesser degree and the VLDL cholesterol/triglyceride ratio was lower in HuCIITg mice and $<0.05$. The elevation of triglyceride relative to cholesterol, phospholipid and protein is suggestive of a predominance of large VLDL particles. IDL + LDL fractions were similar. An increase in HDL total protein/phospholipid ratio was noted in HuCIITg mice. Similar results were obtained from another pooled sample that did not undergo ultracentrifugal reisolation of lipoprotein fractions. A higher VLDL protein and an increased recovery of HDL were noted in the singly-spun pool, as would be expected as a result of lower purity and decreased losses in preparation.

We further characterized the hypertriglyceridemic phenotype by analyzing apolipoprotein compositional changes. SDSPAGE was performed on ultracentrifugally isolated Chylos + VLDL from control, HuCIITg, and HuCIITg $\beta$ NF-induced mice in both the fed and fasted states (Fig. 5). The 9 a.m. bloods taken to represent the fed state are $\sim 7 \mathrm{~h}$ past the usual completion of feeding by mice. There was a marked increase in the apoC band and a decrease in the apoE band in HuCIITg mice in both the fasted and fed states. ApoE decreased further

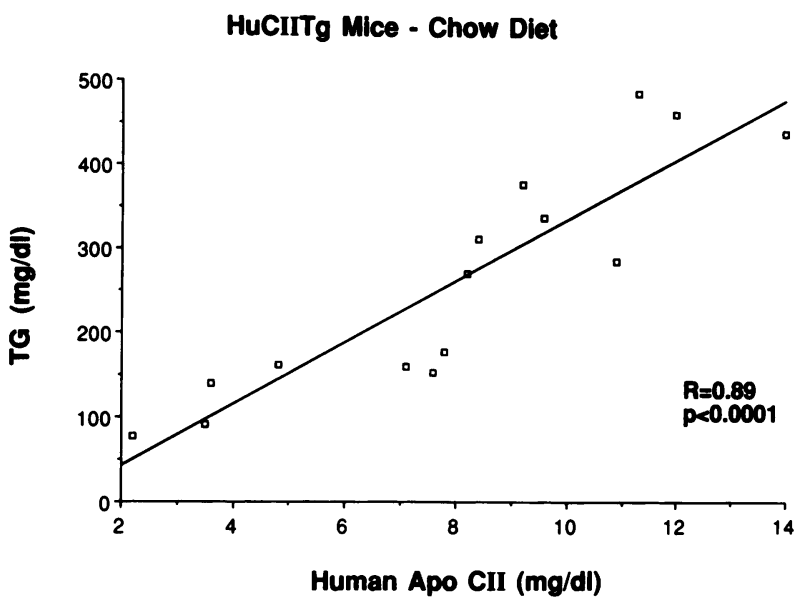

Figure 3. Correlation of triglyceride and human apoCII levels after overnight fasting in HuCIITg mice, noninduced. The blood samples used for the correlation of human apoCII level and triglyceride were drawn at 9 a.m., with food removed the previous 6 p.m. Triglyceride levels were elevated and highly correlated to the human apoCII levels, as indicated.

after induction and, in the fed state, became barely detectable. $\mathrm{ApoC} /$ apoE ratios, as quantitated by laser densitometry, confirmed the marked decrease in apoE relative to apoC. In the fed state, the apoC/apoE ratio increased from 0.43 in controls to 6.94 in transgenics, and to 30.3 in transgenics after induction. SDS-PAGE of HDL and IDL/LDL (data not shown) did not show an increase in apoC or other change in apolipoprotein relative composition.

To shed light on the mechanism of hypertriglyceridemia in these animals, we assessed the relative contributions of overproduction and decreased clearance of VLDL triglyceride by performing turnover studies using in vivo-labeled control VLDL. Similar preparations have been shown to take on the characteristics of the plasma milieu into which they are infused, presumably via rapid apolipoprotein exchange (12). Both transgenic and control mice were, therefore, studied with the same preparations, isolated from control mice. In the animals used in the turnover studies, triglyceride levels $($ mean \pm SD) were $371 \pm 279$ in transgenics and $135.5 \pm 34.4$ in controls. Calculated fractional catabolic rates in pools/ hour \pm SD were $3.5 \pm 3.6$ in transgenics vs $17.7 \pm 12.6$ in controls $(P<0.02)$, pointing to a clearance defect in the transgenic animals.

Table I. Effect of $\beta N F$ Induction on Plasma Lipids and apoCII in Fasting HuCIITg Mice

\begin{tabular}{|c|c|c|c|c|c|c|c|}
\hline & \multicolumn{3}{|c|}{ Triglyceride } & \multicolumn{2}{|c|}{ Cholesterol } & \multicolumn{2}{|c|}{ Human apoClI } \\
\hline & Basal & Vehicle & Induced & Basal & Induced & Basal & Induced \\
\hline $\begin{array}{r}\text { HuCIITg } \\
n=12\end{array}$ & $305 \pm 48$ & $476 \pm 93^{*}$ & $792 \pm 77^{\ddagger}$ & $104 \pm 6^{\prime \prime}$ & $133 \pm 9$ & $26.1 \pm 4$ & $38.3 \pm 1^{\prime}$ \\
\hline $\begin{array}{r}\text { Control } \\
n=6\end{array}$ & $62 \pm 5$ & $80 \pm 10$ & $101 \pm 13^{\S}$ & $74 \pm 12$ & $81 \pm 5$ & & \\
\hline
\end{tabular}

Blood was drawn at 5 p.m., after removal of food at 8 a.m. Induced, $9 \mathrm{~h}$ after the intraperitoneal injection of $2.8 \mathrm{mg} \beta \mathrm{NF}$ in $200 \mu \mathrm{l}$ of corn oil. Vehicle, injection of $200 \mu \mathrm{l}$ of the corn oil vehicle alone. All values are $\mathrm{mg} / \mathrm{dl} \pm \mathrm{SEM}$. Basal and induced human apoCII levels were performed on five HuCIITg animals only. ${ }^{*} P=\mathrm{NS}$ vs basal. ${ }^{\ddagger} P<0.001$ vs vehicle; ${ }^{8} P=$ NS vs vehicle; $" P<0.05$ vs controls; ' $P<0.03$ vs basal. Statistical analyses (paired or unpaired $t$ test) compared the logarithm of triglyceride levels and the cholesterol levels as measured. All triglyceride levels in HuCIITg mice were significantly elevated relative to controls at $P<0.001$, as was the induced cholesterol level. 


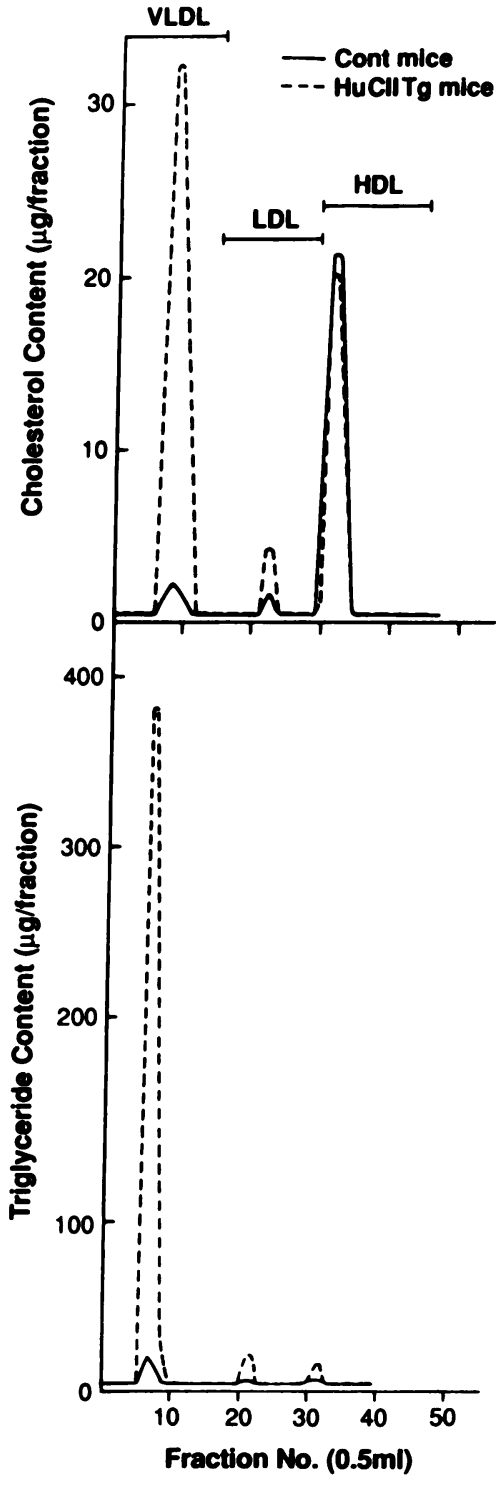

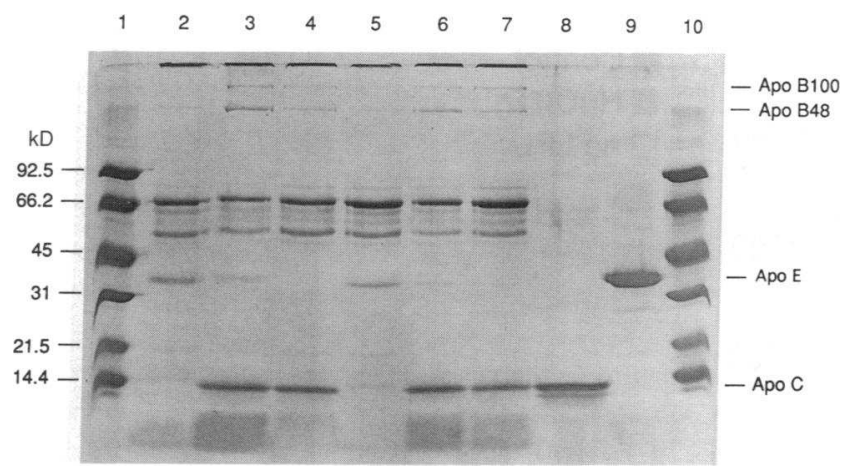

Figure 4. Cholesterol and triglyceride content of gel filtration chromatography fractions of a pool of plasma from HuCIITg and control mice. Plasma samples were obtained in the fed state without $\beta N F$ induction and were drawn at 9 a.m. Size fractions were labeled according to their equivalent density fractions as follows: VLDL, LDL, and HDL. There is marked triglyceride enrichment of all lipoprotein fractions, most prominently of VLDL. VLDL cholesterol content is markedly increased on an absolute basis, but retriglyceride. LDL (+IDL) cholesterol is moderately increased and HDL cholestero minimally decreased. mains $<10 \%$ of VLDL

VLDL production rates were also calculated from the turnover data and were significantly lower in transgenic vs control mice, $0.3 \pm 0.16$ vs $0.75 \pm 0.5 \mathrm{mg} / \mathrm{h} \cdot \mathrm{g}(P<0.05)$. However, since autologous VLDL tracers were not used in these studies, these values are only estimates of VLDL turnover. Triglyceride production was, therefore, directly assessed after inhibition of lipases by intravenous Triton WR 1339. Triglyceride produc-
Figure 5. SDS-PAGE with 3-15\% polyacrylamide gradient. Lanes 1 and 10 contain low molecular weight SDS-PAGE standards (Pharmacia Fine Chemicals); their molecular weight in kilodaltons appears on the left side of the figure. Lanes 2, 3, and 4 contain VLDL/chylomicrons from the fed state from control, HuCIITg mice, and postinduction HuCIITg mice, respectively. Lanes 5-7 are in the same order and reflect the fasted state. Lane 8 is purified human apoCII and lane 9 purified human apoE. The location of apoB 100 , apoB48, apoE, and apoCII/apoCIII is indicated on the right side of the figure. The apoB $100 / \mathrm{apoB} 48$ ratios are approximately constant and consistent, in mice, with a predominant hepatic origin of triglyceride-rich lipoproteins. The apoCII/CIII band is increased in HuCIITg mouse VLDL. The apoE band is dramatically decreased and, in the fed state, decreases further after transgene promoter induction with $\beta \mathrm{NF}$.

tion rates as measured by this technique were $($ mean $\pm \mathrm{SD})$ $0.085 \pm 0.037 \mathrm{mg} / \mathrm{h} \cdot \mathrm{g}$ in controls vs $0.062 \pm 0.061 \mathrm{mg} / \mathrm{h} \cdot \mathrm{g}$ in HuCIITg mice, a nonsignificant difference. Clearly, by both techniques, overproduction of triglyceride-rich particles did not appear to play a role in the etiology of HuCIITg hypertriglyceridemia.

To better define the mechanism of the observed catabolic defect, we assessed the ability of plasma from HuCIITg mice to activate LPL. Lipase assays were performed using both control and HuCIITg plasma to activate partially purified mouse LPL. The mouse enzyme was used because of the possibility of interspecies incompatibility between human apoCII and mouse LPL. As shown in Fig. 6, varying amounts of plasma from both control and HuCIITg mice produced similar activation of lipolysis over a wide range of activity. Studies were also performed using purified in vivo-labeled VLDL from control or HuCIITg mice as the substrate (data not shown). No difference was seen in the triglyceride hydrolysis of the two preparations in a solution assay.

Finally, VLDL binding to heparin-Sepharose was assessed using control and HuCIITg VLDL preparations. There was

Table II. Lipoprotein Composition of HuCIITg and Control Mice, Fed

\begin{tabular}{|c|c|c|c|c|c|c|c|c|c|c|c|c|}
\hline & \multicolumn{4}{|c|}{ Chylos + VLDL } & \multicolumn{4}{|c|}{$\mathrm{IDL}+\mathrm{LDL}$} & \multicolumn{4}{|c|}{ HDL } \\
\hline & TG & C & PL & PR & TG & C & PL & PR & TG & C & PL & PR \\
\hline \multirow[t]{2}{*}{ CII } & 228 & 10 & 51 & 23 & 3 & 5 & 11 & 7 & 4 & 20 & 29 & 68 \\
\hline & $73 \%$ & $3 \%$ & $16 \%$ & $7 \%$ & $9 \%$ & $21 \%$ & $43 \%$ & $27 \%$ & $3 \%$ & $17 \%$ & $24 \%$ & $56 \%$ \\
\hline \multirow[t]{2}{*}{ Con } & 68 & 5 & 20 & 11 & 3 & 4 & 7 & 6 & 0.6 & 12 & 39 & 44 \\
\hline & $65 \%$ & $5 \%$ & $19 \%$ & $11 \%$ & $15 \%$ & $21 \%$ & $33 \%$ & $31 \%$ & $1 \%$ & $12 \%$ & $41 \%$ & $46 \%$ \\
\hline
\end{tabular}

Blood was drawn at 9 a.m., with the animals having ad lib access to food. CII, HuCIITg mice. Con, nontransgenic litter mates. Chylos, chylomicrons; IDL, intermediate density lipoproteins. TG, triglycerides; C, cholesterol; PL, phospholipids; PR, total protein (all measured in milligrams per deciliter whole plasma). \%, percent composition by weight relative to the sum of TG, C, PL, and PR. 


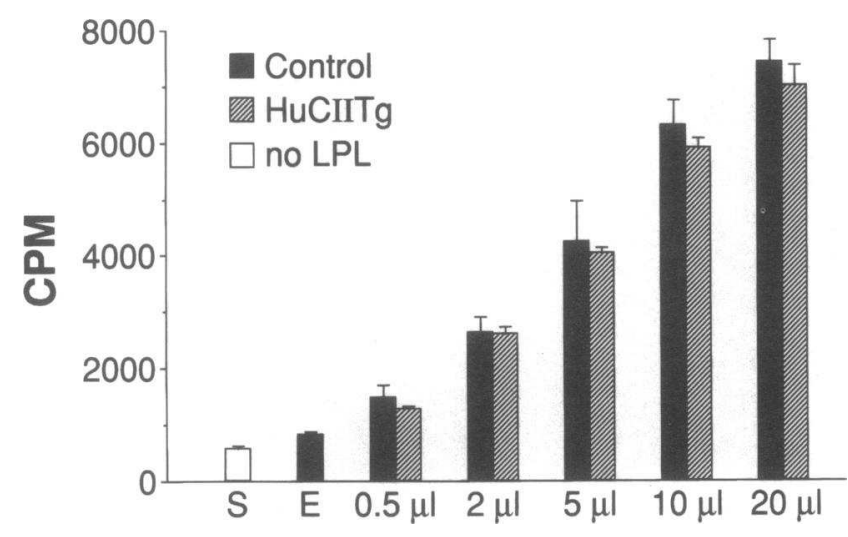

Figure 6. Results of lipase assay (in cpm of $\left[{ }^{3} \mathrm{H}\right]$ oleic acid) using partially purified mouse lipoprotein lipase and varying amounts of either control or HuCIITg plasma (fasting state) to activate a Triton $\mathrm{X}$-100-emulsified triolein substrate. $S$, substrate alone; $E$, enzyme (mouse LPL) plus substrate without plasma; $C P M$, $\mathrm{cpm}$ of ${ }^{3} \mathrm{H}$ oleic acid. The amount of plasma added is indicated at the bottom of the figure. Activation of mouse LPL is approximately equal by control and HuCIITg mouse plasma.

approximately fourfold greater adherence of control VLDL vs HuCIITg VLDL to this gel (Fig. 7), a model for the cell surface glycosaminoglycan matrix. Both heparin-releasable $(P$ $=0.006)$ and non-heparin-releasable $(P=0.0013)$ binding of transgenic VLDL were significantly decreased.

\section{Discussion}

In the present study, we report the creation of a human apoCII transgenic mouse using the CYPIA1 promoter, a novel system for the regulatable expression of a transgene. The CYPIA1 promoter was chosen because of its high degree of inducibility and lack of constitutive expression in mice during intrauterine life (32). This construction allowed the establishment of a line of transgenic mice expressing human apoCII. HuCIITg mice exhibited highly variable expression of the transgene, allowing us to demonstrate the correlation of triglyceride and human apoCII levels over a wide range of values. The reason for this variability in expression is unknown. However, inducibility of the CYPIAl gene has been reported to vary significantly among

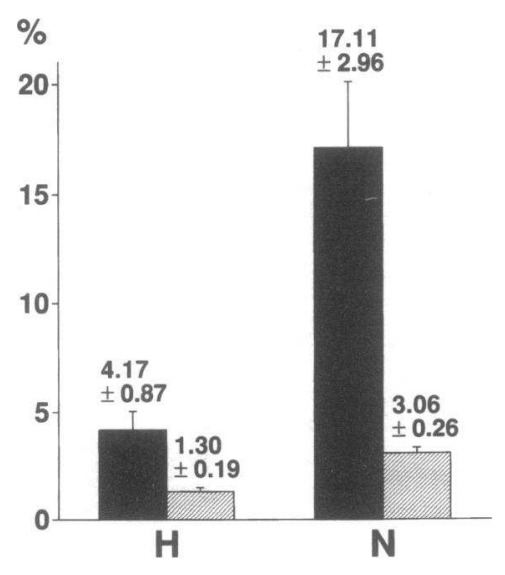

Figure 7. Binding of in vivo-labeled VLDL from both control and HuCIITg mice to heparin Sepharose. $500 \mu 1$ containing $50 \mu \mathrm{g}$ of control or HuCIITg VLDL was incubated for $2 \mathrm{~h}$ at $37^{\circ} \mathrm{C}$ with 500 $\mu \mathrm{l}$ heparin-Sepharose. The percent of VLDL associated with the gels is shown ( mean $\pm \mathrm{SD}$ of triplicate experiments). $H$, heparin-releasable binding; $N$, non-heparin-releasable binding.

There is significantly more binding of control VLDL $(P=0.006$ for $\mathrm{H}, P=0.0013$ for N). $₫$, Control; $:$ HuCIITg. strains of inbred mice. The animals used in these experiments were outbred. Two of the strains that contributed to the genetic makeup of these mice have been shown to have highly different responses to CYPIA1 inducers. C57BL/6 mice exhibit CYPIA1 inducibility by polyaromatic hydrocarbons to which DBA / 2 mice are essentially unresponsive (33). Genetic differences among the mice studied and the presence of trace inducers in the environment may have accounted for the variability in expression of human apoCII.

The association of overexpression of apoCII, the cofactor for the hydrolysis of triglyceride by LPL, with hypertriglyceridemia in transgenic mice was unexpected. Our studies indicated a catabolic defect, which might have been present at the level of either particle clearance or lipolysis. All three $\mathrm{C}$ apolipoproteins have been shown to interfere with the apoE-mediated hepatic uptake of triglyceride-rich particles $(7,8,34)$, and apoCI and apoCII interfere significantly with the binding of $\beta$-migrating VLDL to lipoprotein receptor-related protein (9). However, if excess apoCII in HuCIITg mice were acting by interfering with remnant clearance, through the observed decrease in VLDL apoE, a greater elevation of plasma cholesterol would have been anticipated. Transgenic mice expressing a mutant human apoE defective in both receptor and heparin binding are hypertriglyceridemic and hypercholesterolemic with cholesterol enrichment of VLDL despite the absence of plasma cholesteryl-ester transfer protein activity in this species (35). ApoE-null mice are severely hypercholesterolemic with only minimal elevation of triglyceride $(36,37)$. In contrast, lipoprotein compositional analysis in our HuCIITg mice did not show cholesterol enrichment of VLDL. Indeed, compositional studies revealed increased amounts of large triglyceriderich VLDL, a finding most consistent with a lipolytic defect. Furthermore, a primary delay in remnant clearance, which should occur after most of the VLDL-triglyceride has been hydrolyzed, would seem unlikely to produce the degree of impairment in VLDL-triglyceride removal from the plasma that we observed in our turnover studies. The presence of a remnant removal defect coexisting with a lipolytic defect cannot be ruled out, as the decreased formation of remnant particles (caused by defective lipolysis) would compensate for their decreased clearance. Decreased particulate uptake of larger VLDL, which has been favored as a mechanism in human apoCIII transgenic (HuCIIITg) mice, remains a possibility (12).

How could overexpression of apoCII cause a lipolytic defect? Mutation of the introduced gene was excluded by DNA sequence analysis of the p450CII DNA construction. Another possibility is that human apoCII, or excess apoCII in general, is inhibitory to mouse LPL. At high levels, apoCII has been shown to directly inhibit LPL (2). The lipase assay results showed similar degrees of activation of mouse LPL by a wide range of plasma concentrations from both control and $\mathrm{Hu}-$ CIITg mice. Clearly, the (increased) apoCII in the transgenic plasma was less potent as an activator but there was no evidence of inhibition. Direct hydrolysis of endogenously labeled VLDL was also indistinguishable, but higher local concentrations of apoCII may be present in vivo. A third possibility is that excess apoCII may impair lipolysis by decreasing the access of lipoprotein particles to lipases, either directly, or indirectly by displacing apoE. ApoCII has been shown to decrease the association of LPL with phospholipid vesicles (38), while apoE has been shown to increase the binding and enhance the hydrolysis of a triglyceride emulsion by heparin-Sepharose- 
bound LPL (39). ApoE also enhanced lipolysis of emulsions by hepatic lipase bound to heparin-Sepharose, an effect opposed by both apoCII and apoCIII (40). In vivo, apoE could facilitate access of lipoprotein particles to the negatively charged glycosaminoglycan matrix, where cell surface lipases reside. Proteoglycan interaction with apoE has also been shown to be important in facilitating receptor-mediated lipoprotein binding and uptake by cells (41). Nevertheless, the apparent displacement of apoE by apoCII, as would have been expected (8), does not establish an etiologic role for decreased VLDL apoE in the observed hypertriglyceridemia. In fact, it has been suggested that certain newly-secreted VLDL lack apoE and require lipolysis before they will bind apoE to any significant degree (42). Decreased VLDL apoE may be a marker of excess apoCII binding rather than a mediator of defective lipolysis in HuCIITg mice. Indeed, the absence of significant hypertriglyceridemia in the extreme case of total apoE deficiency, as seen in apoE null mice, argues against the importance of any apoE-related mechanism in HuCIITg mice (36). Excess apoCII may itself be interfering with the association of triglyceride-rich lipoproteins with glycosaminoglycans in $\mathrm{HuCIITg}$ mice, as has been shown for both apoCII and apoCIII in vitro (40). This could impair either lipolysis or particle clearance. Our data show that HuCIITg VLDL is defective in its interaction with heparin-Sepharose. We postulate that a similar defect may occur at the cell surface in the interaction of VLDL with cell surface lipases or receptors. Whether this is caused by excess apoCII, decreased apoE, or both remains unanswered.

All three $\mathrm{C}$ apolipoproteins may, in some respects, play similar roles. ApoCI and apoCII Human apoCI transgenic mice are known to be hypertriglyceridemic (10) as are HuCIIIT mice (12). The correlation between levels of apoCIII and triglyceride levels in HuCIIITg mice appears similar to that of apoCII and triglyceride in HuCIITg mice (12). This holds true, despite the fact that apoCI and apoCIII inhibit lipoprotein lipase activity in solution assays, at levels where apoCII remains an activator $(1,2,43)$. Moreover, VLDL from HuCIIITg and HuCIITg mice are compositionally similar and, in kinetic studies, show a decreased fractional catabolic rate for triglyceride without an increase in production rate. There is also normal hydrolysis of HuCIITT VLDL by LPL in a solution assay (12).

$\mathrm{HuCIITg}$ mice are a potentially instructive model of hypertriglyceridemia and raise the possibility that overexpression of apoCII may have a role in human disease. Future experiments will further address the role of $\mathrm{C}$ apolipoproteins in the interaction of triglyceride-rich lipoproteins with lipoprotein receptors, LPL, and hepatic lipase at the cell surface and within glycosaminoglycan matrices.

\section{Acknowledgments}

We thank Katriina Aalto-Setälä for valuable discussion, and Hai-Ying Fan, Ruben Peraza, Theresa Vanni, and Kyriakos Economides for expert technical assistance.

This research was supported by National Institute of Health grants HL-33714, HL-32435, HL-21006, HL-36000, and HL-45095, the Calder Foundation, and by a Roth Foundation grant to N. S. Shachter.

\section{References}

1. LaRosa, J. C., R. I. Levy, P. Herbert, S. E. Lux, and D. S. Frederickson. 1970. A specific apoprotein activator for lipoprotein lipase. Biochem. Biophys. Res. Commun. 41:57-62.
2. Havel, R. J., C. J. Fielding, T. Olivecrona, V. G. Shore, P. E. Fielding, and T. Egelrud. 1973. Cofactor activity of protein components of human very low density lipoproteins in the hydrolysis of triglycerides by lipoprotein lipase from different sources. Biochemistry. 12:1828-1833.

3. Cox, D. W., W. C. Breckenridge, and J. A. Little. 1978. Inheritance of apolipoprotein C-II deficiency with hypertriglyceridemia and pancreatitis. $N$. Engl. J. Med. 299:1421-1424.

4. Wang, C. S. 1991. Structure and functional properties of apolipoprotein C-II. Prog. Lipid Res. 30:253-258.

5. Santamarina-Fojo, S. 1992. Genetic dyslipoproteinemias: role of lipoprotein lipase and apolipoprotein C-II. Curr. Opin. Lipidol. 3:186-195.

6. Hegele, R. A., W. C. Breckenridge, D. W. Cox, G. F. Maguire, J. A. Little, and P. W. Connelly. 1991. Interaction between variant apolipoproteins C-II and E that affects plasma lipoprotein concentrations. Arterioscler. Thromb. 11:13031309.

7. Windler, E., Y.-S. Chao, and R. J. Havel. 1980. Determinants of hepatic uptake of triglyceride-rich lipoproteins and their remnants in the rat. J. Biol. Chem. 255:5475-5480.

8. Windler, E., and R. J. Havel. 1985. Inhibitory effects of $C$ apolipoproteins from rats and humans on the uptake of triglyceride-rich lipoproteins and their remnants by the perfused rat liver. J. Lipid Res. 26:556-565.

9. Weisgraber, K. H., R. W. Mahley, R. C. Kowal, J. Herz, J. L. Goldstein and M. S. Brown. 1990. Apolipoprotein C-I modulates the interaction of apolipoprotein $\mathrm{E}$ with $\beta$-migrating very low density lipoproteins ( $\beta$-VLDL) and inhibits binding of $\beta$-VLDL to low density lipoprotein receptor-related protein. J. Biol. Chem. 265:22453-22459.

10. Simonet, W. S., N. Bucay, R. E. Pitas, S. J. Lauer, and J. M. Taylor. 1991. Multiple tissue-specific elements control the apolipoprotein E/C-I gene locus in transgenic mice. J. Biol. Chem. 266:8651-8654.

11. Ito, Y., N. Azrolan, A. O'Connell, A. Walsh, and J. L. Breslow. 1990. Hypertriglyceridemia as a result of human apo CIII gene expression in transgenic mice. Science (Wash. DC). 249:790-793.

12. Aalto-Setälä, K., E. A. Fisher, X. Chen, T. Chajek-Shaul, T. Hayek, R. Zechner, A. Walsh, R. Ramakrishnan, H. N. Ginsberg, and J. L. Breslow. 1992. Mechanism of hypertriglyceridemia in human apo CIII transgenic mice: diminished VLDL fractional catabolic rate associated with increased apo CIII and reduced apo E on the particles. J. Clin. Invest. 90:1889-1900.

13. Shachter, N. S., Y. Zhu, A. Walsh, J. L. Breslow, and J. D. Smith. 1993. Localization of a liver-specific enhancer in the apolipoprotein $\mathrm{E} / \mathrm{CI} / \mathrm{CII}$ gene locus. J. Lipid Res. 34:1699-1708.

14. Rosenberg, D. W., and T. Leff. 1993. Regulation of cytochrome P450 in cultured human colonic cells. Arch. Biochem. Biophys. 300:186-192.

15. Okey, A. B. 1990. Enzyme induction in the cytochrome P-450 system. Pharmacol. \& Ther. 45:241-298.

16. Jaiswal, A. K., F. J. Gonzalez, and D. W. Nebert. 1985. Human $P_{1}-450$ gene sequence and correlation of mRNA with genetic differences in benzo[a]pyrene metabolism. Nucleic Acids Res. 13:4503-4520.

17. Smit, M., E. v. d. Kooijs-Meis, L. P. Woudt, L. M. Havekes, and R. R. Frants. 1988. Exact localization of the familial dysbetalipoproteinemia associated Hpal restriction site in the promoter region of the APOCI gene. Biochem. Biophys. Res. Commun. 152:1282-1288.

18. Walsh, A., Y. Ito, and J. L. Breslow. 1989. High levels of human apolipoprotein A-I in transgenic mice result in increased plasma levels of small high density lipoprotein (HDL) particles comparable to human $\mathrm{HDL}_{3}$. J. Biol. Chem. 264:6488-6494.

19. Jackson, C. L., G. A. P. Bruns, and J. L. Breslow. 1984. Isolation and sequence of a human apolipoprotein CII cDNA clone and its use to isolate and map to human chromosome 19 the gene for apolipoprotein CII. Proc. Natl. Acad. Sci. USA. 81:2945-2949.

20. Feinberg, A. P., and B. Vogelstein. 1983. A technique for radiolabelling DNA restriction endonuclease fragments to high specific activity. Anal. Biochem. 132:6-13.

21. Rosenberg, D. W. 1991. Dietary modulation of cytochrome P-450 in the small intestinal epithelium. Pharmacology. 43:36-46.

22. Rosenberg, D. W. 1991. Tissue-specific induction of the carcinogen inducible cytochrome P450 isoform, P450IAI, in colonic epithelium. Arch. Biochem. Biophys. 284:223-226.

23. Smith, J. D., A. S. Plump, T. Hayek, A. Walsh, and J. L. Breslow. 1990. Accumulation of human apolipoprotein $\mathrm{E}$ in the plasma of transgenic mice. $J$. Biol. Chem. 265:14709-14712.

24. Bartlett, G. R. 1959. Phosphorus assay in column chromatography. $J$. Biol. Chem. 234:466-468.

25. Havel, R. J., H. A. Eder, and J. H. Bragdon. 1955. The distribution and chemical composition of ultracentrifugally separated lipoproteins in human serum. J. Clin. Invest. 34:1345-1353.

26. Lowry, O. H., N. J. Rosebrough, A. L. Farr, and R. J. Randall. 1951. Protein measurement with the folin phenol reagent. J. Biol. Chem. 193:265-275.

27. Weber, K., and M. Osborn. 1969. The reliability of molecular weight determinations by dodecyl sulfate-polyacrylamide gel electrophoresis. J. Biol. Chem. 244:4406-4412. 
28. Ginsberg, H. N., N.-A. Le, and J. C. Gibson. 1985. Regulation of the production and catabolism of plasma low density lipoproteins in hypertriglyceridemic subjects: effect of weight loss. J. Clin. Invest. 75:614-623.

29. Augustin, J., H. Freeze, P. Tejada, and W. V. Brown. 1978. A comparison of molecular properties of hepatic triglyceride lipase and lipoprotein lipase from human post-heparin plasma. J. Biol. Chem. 253:2912-2920.

30. Brinton, E. A., S. Eisenberg, and J. L. Breslow. 1989. Elevated high density lipoprotein cholesterol levels correlate with decreased apoA-I and apoA-II fractional catabolic rate in women. J. Clin. Invest. 84:262-269.

31. Ishibashi, S., T. Murase, K. Takahashi, N. Mori, M. Kawakami, and F. Takaku. 1986. Plasma apolipoprotein CII levels in hypertriglyceridemia. Metabo lism. 35:781-785.

32. Dey, A., H. Westphal, and D. W. Nebert. 1989. Cell-specific induction of mouse CypIAl mRNA during development. Proc. Natl. Acad. Sci. USA. 86:7446-7450.

33. Whitlock, J. P. 1986. The regulation of cytochrome P-450 gene expression. Ann. Rev. Pharmacol. Toxicol. 26:333-369.

34. Shelburne, F., J. Hanks, W. Meyers, and S. Quarfordt. 1980. Effect of apoproteins on hepatic uptake of triglyceride emulsions in the rat. J. Clin. Invest. 65:652-658

35. Fazio, S., W. S. Simonet, and S. C. Rall, Jr. 1992. Hepatic expression of a receptor-binding-defective human apolipoprotein $\mathrm{E}$ variant creates a model of type III hyperlipoproteinemia in transgenic mice. Circulation. 86:I-278. (Abstr.)

36. Plump, A. S., J. D. Smith, T. Hayek, K. Aalto-Setälä, A. Walsh, J. G.
Verstuyft, E. M. Rubin, and J. L. Breslow. 1992. Severe hypercholesterolemia and atherosclerosis in apolipoprotein E-deficient mice created by homologous recombination in ES cells. Cell. 71:1-20.

37. Zhang, S. H., R. L. Reddick, J. A. Piedrahita, and N. Maeda. 1992 Spontaneous hypercholesterolemia and arterial lesions in mice lacking apolipoprotein E. Science (Wash. DC). 258:468-472.

38. Shirai, K., N. Matsuoka, and R. L. Jackson. 1981. Interaction of lipoprotein lipase with phospholipid vesicles. Role of apolipoprotein C-II and heparin Biochim. Biophys. Acta. 665:504-510.

39. Clark, A. B., and S. H. Quarfordt. 1985. Apolipoprotein effects on the lipolysis of perfused triglyceride by heparin-immobilized milk lipase. J. Biol. Chem. 260:4778-4783.

40. Landis, B. A., F. S. Rotolo, W. C. Meyers, A. B. Clark, and S. H. Quarfordt. 1987. Influence of apolipoprotein $\mathrm{E}$ on soluble and heparin-immobilized hepatic lipase. Am. J. Physiol. 252:G805-G810.

41. Ji, Z.-S., W. J. Brecht, R. D. Miranda, M. M. Hussain, T. L. Innerarity, and R. W. Mahley. 1993. Role of heparan sulfate proteoglycans in the binding and uptake of apolipoprotein E-enriched remnant lipoproteins by cultured cells J. Biol. Chem. 268:10160-10167.

42. Ishikawa, Y., C. J. Fielding, and P. E. Fielding. 1988. A change in apolipoprotein $B$ expression is required for the binding of apolipoprotein $E$ to very low density lipoprotein. J. Biol. Chem. 263:2744-2749.

43. Brown, W. V., and M. L. Baginsky. 1972. Inhibition of lipoprotein lipase by an apoprotein of human very low density lipoprotein. Biochem. Biophys. Res. Commun. 46:375-382. 